\title{
Analysis of the decision on the fresh milkfish purchase by using Analytic Hierarchy Process method (AHP)
}

\author{
Ribangun Bamban Jakaria ${ }^{1}$, and Wiwik Sulistiyowati ${ }^{1}$ \\ ${ }^{1}$ Universitas Muhammadiyah Sidoarjo, Industrial Engineering Department, Jl. Mojopahit 666 B, Sidoarjo 61271, Jawa Timur, Indonesia
}

\begin{abstract}
The milkfish buying decision of the customers in traditional markets has a variety of purposes; it is based on the interests of each customer. However, the selection made generally has the same reason, that is on the basis on the quality of the milkfish. Different harvesting process leads to different quality of the fish catch, therefore the milkfish purchasing becomes an interesting phenomenon to be conducted as a research. This study aims to find out the reason of the customers in making decision to buy milkfish by examining the alternative choice of three harvesting ways such as the process of harvesting by using the net, mérék (pushing the milkfish to a one point), ngesat ( draining the pond), by looking at the quality of milkfish which is categorized from the texture, gills, eye, smell and mucus on the surface of the body. This study uses Analytic Hierarchy Process (AHP) method. The finding shows that harvesting by using mérék (pushing milkfish to one point) results good quality of fish catch seen from the texture of milkfish, gills, and smell.
\end{abstract}

\section{Introduction}

Fish is a food that is often popular and consumed by the community because it is rich in essential nutrients such as proteins, vitamins, omega-3 fatty acids. Types of fish that are often consumed by the community are diverse. Increased by the public awareness to meet the nutritional needs of animal protein encourages people to buy fresh fish that have good quality [1]. One type of fresh fish that is widely consumed by the community one of them is milkfish. Milkfish (ChanosChanos) is a type of brackish water fish that has a savory taste and a high protein source of about $20 \%$, low fat content of about $0.6 \%$ [1]. Milkfish can be bought freshly or being processed into, such as Pepes; processed milkfish without thorns, brains.

The quality of milkfish harvest is influenced by the techniques of harvest execute by ponds' farmers. There are 3 techniques of milkfish harvesting by traditional farmers. The first one is using the net, which is fish catcher tool, bird, and so on in the form of knitted rope that make eye [2]. Next is mêrêk, which is a technique of milkfish harvesting by pushing milkfish to the corner of the pond into a special net placed in the corner of the pond. The last one is harvesting by draining the pond or ngesat.

Before deciding to buy fresh fish, consumers must first go through the process of making purchasing decisions. There are five stages in the process of making purchasing decisions namely the introduction to problems, searching information, alternative evaluation, purchasing decisions, post-purchasing behavior [3]. Consumer attitudes are important factors that can influence consumers in making purchasing decisions of milkfish by taking into account the attributes that exist in milkfish such as scales, smell, textures, gills, eyes. The pattern of the agricultural distribution center is needed for management to be more careful given the nature of perishable products[4].

Method for decision making using Analytic Hierarchy Process (AHP) method. AHP is a method for making effective decisions on complex issues by simplifying and accelerating the decision-making process[5]. The results obtained from the AHP process can be used as a tool to support decision-making (DSSDecision Support System) [6]. The advantages of the AHP method, among others, can explain the decisionmaking process that can be graphically depicted so easily understood by all parties involved in decision-making, the hierarchy structure as a consequence of the selected criteria until sub-criteria are detailed and selected. The purpose of this research is to understand the interest of milkfish buyer based on the harvesting techniques by comparing the fundermental variables in milkfish including texture, gills, eyes, aroma and scalesusing Analytic Hierarchy Process (AHP) method.

\footnotetext{
* Corresponding author: ribangunbz@,umsida.ac.id
} 


\section{Methodology}

\subsection{Data collection}

Data collection in this study was conducted by using a tool in the form of questionnaires distributed to the respondents who became the sample in this study.

\subsection{Data analysis}

The data were obtained through in-depth interviews and research questionnaires. The data obtained is processed using Analytical Hierarchy Process (AHP) analysis [7]. This process of analytic hierarchy allows decision makers to describe the simultaneous interaction of many factors in complex and unstructured situations [8]. Selection Data obtained from the results of paired comparison questionnaires processed with the help of Expert Choice 2000 and Microsoft Excel 2007. The basic principle of AHP is as follows:

- Reciprocal Comparison i.e. decision making should contain a comparison and express its preference. Preference must be eligible for reciprocal when A is preferred over $\mathrm{B}$ with scale $\mathrm{x}$, then $\mathrm{B}$ is preferable to A with scale $1 / \mathrm{x}$

- Homogeneity that one's preference must be expressed on a limited scale or its elements can be compared to one another. If this axiom is not met then the comparable element is not homogeneous and a new group of elements must be formed.

- Independence is a preference by assuming that the criterion is not influenced by the existing alternative but by the overall objective, which means that the ratio of the elements in one level is influenced or dependent by the elements on the level above it.

- Expectation is the purpose of decision makers. The structure of the hierarchy is assumed to be complete. If the assumption is not met then the decision maker does not use all the available criteria or objectives therefore the decision taken is considered incomplete.

To determine the priority of some criteria by performing pairwise comparison analysis of each criterion and to perform AHP calculation process need to understand the principle of AHP that is [9]:

- Determination of decision components (objectives, criteria and alternatives)

- The preparation of the hierarchy of decision components

- Alternative assessments and criteria

- A consistency assessment check

- Prioritizing criteria and alternatives

Criteria and alternatives are assessed through pairwise comparisons. For a variety of issues 1 to 9 scale is the best scale in expressing opinions.
Table 1. Scale of pairwise assessment.

\begin{tabular}{|c|c|}
\hline $\begin{array}{c}\text { Intesity of } \\
\text { Importance }\end{array}$ & Definition \\
\hline 1 & $\begin{array}{c}\text { Both elements are equally } \\
\text { important }\end{array}$ \\
\hline 3 & $\begin{array}{c}\text { One element is slightly more } \\
\text { important than the other } \\
\text { elements }\end{array}$ \\
\hline 5 & $\begin{array}{c}\text { One element is more important } \\
\text { important than any other element }\end{array}$ \\
\hline 7 & $\begin{array}{c}\text { One element is absolutely } \\
\text { essential of any other element }\end{array}$ \\
\hline 9 & $\begin{array}{c}\text { Values between two adjacent } \\
\text { considerations }\end{array}$ \\
\hline $2,4,6$
\end{tabular}

The pairwise comparison process starts from the topmost hierarchy level which is intended to have the criterion $\mathrm{A}$ and then the elements to be compared are A1, A2, A3. The composition of the elements to be compared will be as in the following matrix image [10]:

Table 2. Matched pair matrices.

\begin{tabular}{|c|c|c|c|c|c|}
\hline $\mathrm{G}$ & $\mathrm{A}_{1}$ & $\mathrm{~A}_{2}$ & $\mathrm{~A}_{3}$ & $\cdots \cdots$ & $\mathrm{A}_{\mathrm{n}}$ \\
\hline $\mathrm{A}_{1}$ & $\mathrm{~A}_{11}$ & $\mathrm{~A}_{12}$ & $\mathrm{~A}_{13}$ & $\cdots \cdots$ & $\mathrm{A}_{1 \mathrm{n}}$ \\
\hline $\mathrm{A}_{2}$ & $\mathrm{~A}_{21}$ & $\mathrm{~A}_{22}$ & $\mathrm{~A}_{23}$ & $\cdots \cdots$ & $\mathrm{A}_{2 \mathrm{n}}$ \\
\hline $\mathrm{A}_{3}$ & $\mathrm{~A}_{31}$ & $\mathrm{~A}_{32}$ & $\mathrm{~A}_{33}$ & $\cdots \cdots$ & $\mathrm{A}_{3 \mathrm{n}}$ \\
\hline$\cdots \cdots$ & $\cdots \cdots$ & $\cdots \cdots$ & $\cdots \cdots$ & $\cdots \cdots$ & $\cdots \cdots$ \\
\hline $\mathrm{A}_{\mathrm{n}}$ & $\mathrm{A}_{\mathrm{n} 1}$ & $\mathrm{~A}_{\mathrm{n} 2}$ & $\mathrm{~A}_{\mathrm{n} 3}$ & & $\mathrm{~A}_{\mathrm{nn}}$ \\
\hline
\end{tabular}

\section{Discussion}

Figure 1 above illustrates the purchase decision of milkfish by consumers based on the characteristics of fish. This is greatly influenced by the harvesting practices of tambak farmers. The basis of selection conducted by consumers include the condition of the fish should be clear, which means the fish is still fresh the next texture of the fish should be chewy and solid which means the fish is not rotten, the condition of the scales should also be considered because the condition of scales that many peel off gives an indication that the way of harvest and storage is not good enough, which causes the scales of fish peeled off. The condition of fresh fish can also be seen from the condition of the gill found on the fish head, the fresh fish gills will appear reddish, clean and look fresh and the last is the smell / smell that fish have the aroma of fish and not vice versa mememiliki aroma basuk or smell of soil /mud. 


\subsection{Create a hierarchy of problems}

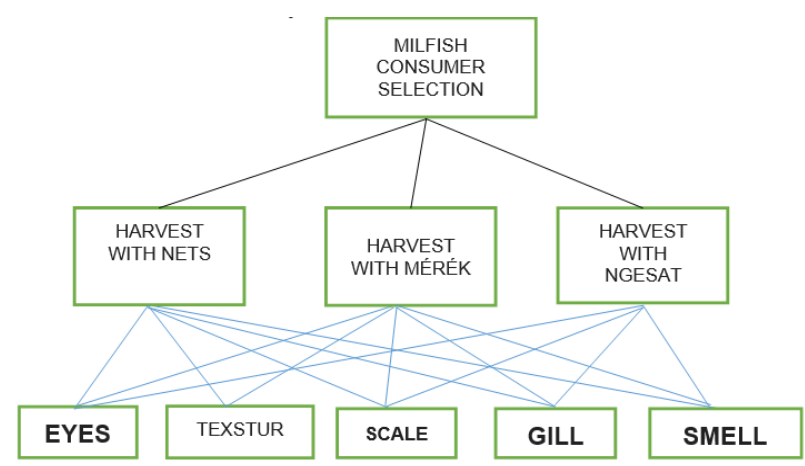

Fig. 1. The hierarchy of the process of selecting milkfish by consumers make a comparison of criteria.

\subsection{Make a comparison of subcreteria}

Table 3 is calculating the comparison of criteria by giving weighting between criteria, by assigning values according to the periority level of the criteria.
Table 3. Calculating the comparison of criteria.

\begin{tabular}{|c|c|c|c|c|c|}
\hline & EYE & TEXSTURE & SCALE & GILL & SMELL \\
\hline EYE & 1,000 & 0,333 & 5,000 & 0,250 & 0,200 \\
\hline TEXSTURE & 3,000 & 1,000 & 2,000 & 0,200 & 0,200 \\
\hline SCALE & 0,200 & 0,500 & 1,000 & 0,200 & 0,200 \\
\hline GILL & 4,000 & 5,000 & 5,000 & 1,000 & 0,500 \\
\hline SMELL & 5,000 & 5,000 & 5,000 & 2,000 & 1,000 \\
\hline Sum & 4,200 & 1,833 & 18,000 & 0,650 & 0,600 \\
\hline
\end{tabular}

\subsection{Calculate the weight of sub criteria}

That is by dividing the total weighted value that has been done step 2 by dividing the value of each column table by the total total value in column Calculates the criteria weight.

Table 4. Calculate the weight of sub criteria.

\begin{tabular}{|c|c|c|c|c|c|c|c|c|}
\hline & EYES & TEXTURE & SCALE & GILL & SMELL & SUMMERY & WEIGHTS & PRIORITY \\
\hline Eyes & 0,081 & 0,034 & 0,250 & 0,052 & 0,141 & 0,558 & 0,112 & 5 \\
\hline Texture & 0,243 & 0,102 & 0,167 & 0,086 & 0,085 & 0,682 & 0,136 & 5 \\
\hline Scale & 0,027 & 0,051 & 0,083 & 0,086 & 0,141 & 0,388 & 0,078 & 5 \\
\hline Gill & 0,405 & 0,305 & 0,250 & 0,259 & 0,211 & 1,430 & 0,286 & 5 \\
\hline Smell & 0,243 & 0,508 & 0,250 & 0,517 & 0,423 & 1,941 & 0,388 & 5 \\
\hline checksum & 1,000 & 1,000 & 1,000 & 1,000 & 1,000 & 5,000 & 1,000 & 25 \\
\hline
\end{tabular}

By weighting the sub criteria, on table 3 , the selection of milkfish conducted by consumer based on aroma $(0,388)$ this explains the consumers want to buy fresh milkfish that must be free from the smell of mud, which is a typical smell of milkfish if the farmers ignore the process of harvesting. On the other hand, gill weights 0.286 which means that the condition of fresh fish can be seen from gills' color or pattern of the fish, if the fish is good or fresh then the color of the gills should be red. Therefore, selecting fish by looking at the condition of the gill is one way that can ensure the consumer to determine the quality of the fish. Texture $(0.136)$ is the next criteria that the consumers considered before buying milkfish. The condition of the fish textures can indicate the quality of the fish, that is by pressing the fish body then it will be implied to know whether the condition of fish is fresh or not. If the body is hard and solid, then it is implied that the fish is fresh. The next one is the condition of the fishes' eyes $(0.112)$ which can determine the freshness factor of fish from the freshness its eyes. if it looks glaucous it means that the fish has already been stored for too long. The last one is the condition of scales $(0.078)$ that is often used as the basis of determination of fish selection. And result $\lambda \max$ $(0,270)$, CI $(-1,183)$ and CR $(-0,011)$ with the result that
$\mathrm{CR}<0,1$ consistent. It is because the good fish is a fish that has a good scales condition (intact and not torn), and these factors have affected the farmers' harvesting methods.

\subsection{Evaluation of choices}

It is used to evaluate how the harvest is carried out by fish farmers to provide conformity to the selection of milkfish conducted by consumers. That is by giving weighting on each of the criteria by giving a scale of 1 9 .

Table 5. Calculate the weight of sub criteria.

\begin{tabular}{|c|c|c|c|}
\hline & Mêrêk & Jaring & Ngesat \\
\hline Mêrêk & 1,00 & 3,00 & 7,00 \\
\hline Jaring & 0,33 & 1,00 & 3,00 \\
\hline Ngesat & 0,14 & 0,33 & 1,00 \\
\hline sum & 1,48 & 4,33 & 11,00 \\
\hline
\end{tabular}




\subsection{Determining the weighting on the criteria}

Determination of weighting done on the type of harvesting criteria to discover the weighted value of 3 types of harvesting methods. It aims to determine which method is the best in harvesting milkfish. This is weighted from the largest to the smallest.

Table 6. Determining the weighting on the criteria.

\begin{tabular}{|c|c|c|c|c|c|c|}
\hline & Mêrêk & Jaring & Ngesat & sum & weight & eigen value \\
\hline Mêrêk & 0,68 & 0,69 & 0,64 & 2,01 & 0,669 & 3 \\
\hline Jaring & 0,23 & 0,23 & 0,27 & 0,73 & 0,243 & 3 \\
\hline Ngesat & 0,10 & 0,08 & 0,09 & 0,26 & 0,088 & 3 \\
\hline checksum & 1,000 & 1,000 & 1,000 & & & 9 \\
\hline
\end{tabular}

$\lambda \max (0,51)$, CI $(-2,24)$ and CR $(-2,14)$ with the result that $\mathrm{CR}<0,1$ consistent.

\subsection{Calculate the alternate weight for each criterion}

By calculating the selected harvest type, the highestscore can be used as the basis for the best selection of the harvest technique [11]. So with the selection of the best technique, it will affect on how the harvest is done by farmers, thus providing better quality fish harvested and increase consumers' interests.

Table 7. Calculate the alternate weight for each criterion.

\begin{tabular}{|c|c|c|}
\hline Net & 1,300 & \\
\hline Mêrêk & 1,341 & hight score \\
\hline Ngesat & 0,448 & \\
\hline checksum & 3,089 & \\
\hline
\end{tabular}

\section{Results}

Mêrêk technique has the highest value in recommending the techniques of milkfish harvest by pond farmers. Mêrêk is a technique of harvesting milkfish by pushing them to the corner of the fishpond, and into a special net placed there, as a result the catch has better quality, with no sloughed scales and no head injury. Therefore the quality of milkfish harvest by this technique will affect the purchasing decision made by consumers, as the choices of purchasing milkfish have been met.

\section{Conclusions}

With the completion of harvesting by pond farmers, it gives the illustration that the quality of the harvest greatly influences purchasing decisions and consumer consumption patterns of milkfish. It is based on test results using AHP which is using variables such as eye quality, texture, scales, gills, smells of milkfish.

\section{References}

1. "Komoditas http://wpi.kkp.go.id/?q=node/46. .

2. "Jaring," https://kbbi.web.id/jaring. .

3. P. Kotler and K. L. Keller, Marketing Management, vol. 22, no. 4. (2009)

4. T. S. Zen and P. Dwiyantoro, Commerce Systems and Distribution Pattern Commodities Principal and Featured (A Case Study in Ciamis District, West Java Province, Indonesia), Procedia - Soc. Behav. Sci., vol. 115, no. Iicies 2013, pp. 34-43, (2014)

5. B. Jovanović, J. Filipović, and V. Bakić, Prioritization of manufacturing sectors in Serbia for energy management improvement - AHP method, Energy Convers. Manag., vol. 98, pp. 225-235, (2015)

6. E Turban, Decision Support and Business Intelligence Systems, 9th ed. Prentice-Hall, Inc. New Jersey.

7. H. Kazan, S. Özçelik, and E. H. Hobikoğlu, Election of Deputy Candidates for Nomination with AHP-Promethee Methods, Procedia - Soc. Behav. Sci., vol. 195, pp. 603-613, (2015)

8. I. Aşchilean, G. Badea, I. Giurca, G. S. Naghiu, and F. G. Iloaie, Choosing the Optimal Technology to Rehabilitate the Pipes in Water Distribution Systems Using the AHP Method, Energy Procedia, vol. 112, no. October 2016, pp. 19-26, (2017)

9. T. U. Daim, A. Udbye, and A. Balasubramanian, Use of analytic hierarchy process (AHP) for selection of 3PL providers, J. Manuf. Technol. Manag., vol. 24, no. 1, pp. 28-51, (2012)

10. T. L. Saaty, "Decision making with the analytic hierarchy process," Int. J. Serv. Sci., vol. 1, no. 1, p. 83, (2008)

11. Y. Lu, H. Xu, Y. Wang, and Y. Yang, Evaluation of water environmental carrying capacity of city in Huaihe River Basin based on the AHP method: A case in Huai'an City, Water Resour. Ind., vol. 18, pp. 71-77, (2017) 